\title{
THE IMPACT OF NON PERFORMING FINANCE (NPF), CAPITAL ADEQUACY RATIO (CAR), AND FINANCING DEPOSIT RATIO (FDR) TO RETURN ON ASSET (ROA) WITH DEPOSITOR FUNDS AS A MODERATING VARIABLE IN ISLAMIC BANKS
}

\author{
Ahmad Syifa \\ University of Pamulang \\ dafa34@gmail.com
}

\begin{abstract}
Return On Asset (ROA) is one of the profitability indicators, this study aimed to know the effect of several internal factors; non performing financing (NPF), capital adequacy ratio $(C A R)$ and financing to deposit ratio $(F D R)$ and depositors funds to Return on Asset (ROA) in Islamic commercial bank in Indonesia. This study uses a sensus method from January 2009 to December 2015. Testing the hypothesis in this study is done by using multiple linier regression test analysis and test interaction moderated regression analysis (MRA) by using Statistical Package for the Social Sciences (SPSS) 23. Result of this research hypothesis show that in the model seen a significant influence on non performing financing and capital adequacy ratio to ROA with probability value (sig-t) 0,000 lower than 0,05, and the value of coefficient regression are -0,349 and -0,114 with negative score, it means that if NPF or CAR increase it can make ROA decreasing. The result of third hypothesis shows that FDR has significant influence to ROA with probability value (sig-t) 0,019 lower than 0,05 and the value of coefficient regression is 0,028, it means that FDR has positive influence to ROA. This study also demonstrates the role of moderating variables that can be seen from the result of fourth until sixth hypothesis testing that significantly influence to ROA with probability value (sig-t) score 0,000, 0,022 and 0,003 lower than 0,05 and have coefficient regression value equal 1,029, 0,391 and 0,073 with positive score. Statistical of $F$ test shows that $F_{\text {cal }}$ equal to 24,053 while $F_{\text {table }}$ at 0,846 , so that $F_{\text {cal }}>F_{\text {table. It means that independent variables }}$ such as NPF, CAR, FDR, and DPK significantly influence to Return on Asset.
\end{abstract}

Keywords: NPF, CAR, FDR, Depositor Funds, ROA

\begin{abstract}
Abstrak
Return On Asset (ROA) adalah salah satu indikator profitabilitas, penelitian ini bertujuan untuk mengetahui pengaruh beberapa faktor internal; non performing financing (NPF), rasio kecukupan modal (CAR), pendanaan untuk simpanan deposito (FDR) dan dana deposan untuk Return on Asset (ROA) di bank komersial Islam di Indonesia. Penelitian ini menggunakan metode sensus dari Januari 2009 hingga Desember 2015. Pengujian hipotesis dalam penelitian ini
\end{abstract}


dilakukan dengan menggunakan analisis regresi linier berganda dan uji interaksi moderated regression analysis (MRA) dengan menggunakan SPSS versi 23. Hasil penelitian hipotesis ini menunjukkan bahwa pada model terlihat pengaruh yang signifikan terhadap non performing financing dan capital adequacy ratio terhadap ROA dengan nilai probabilitas (sig-t) 0,000 lebih rendah dari 0,05 , dan nilai koefisien regresi adalah -0,349 dan - 0,114 dengan skor negatif, artinya jika NPF atau CAR meningkat maka dapat membuat ROA menurun. Hasil hipotesis ketiga menunjukkan bahwa FDR memiliki pengaruh signifikan terhadap ROA dengan nilai probabilitas (sig-t) 0,019 lebih rendah dari 0,05 dan nilai koefisien regresi adalah 0,028, itu berarti bahwa FDR memiliki pengaruh positif terhadap ROA. Penelitian ini juga menunjukkan peran variabel moderating yang dapat dilihat dari hasil pengujian hipotesis keempat hingga keenam yang berpengaruh signifikan terhadap ROA dengan nilai probabilitas (sig-t) skor 0,000, 0,022 dan 0,003 lebih rendah dari 0,05 dan memiliki koefisien regresi. nilai sama 1.029, 0,391 dan 0,073 dengan skor positif. Uji statistik F menunjukkan bahwa Fcal sama dengan 24,053 sedangkan $\mathrm{F}$ tabel pada 0,846 , sehingga $\mathrm{F}$ cal $>\mathrm{F}$ tabel. Ini berarti bahwa variabel independen seperti NPF, CAR, FDR, dan DPK berpengaruh signifikan terhadap Return on Asset.

Kata kunci: NPF, CAR, FDR, Dana Deposan, ROA

\section{INTRODUCTION}

Profitability that projected with high ROA owned by banks will provide banking opportunities to provide financing (funding) for the better society. A good financing volume from sharia banking will drive the economy in the real sector that will improve people's welfare.

From 2013, the profitability of sharia banks projected with ROA decreased by 0.14 percent from the previous year. This is a "red light" for sharia banking companies that previously experienced a significant increase in assets; 31.8 percent. With the decline of ROA in 2013, an evaluation of the factors that may affect the profitability of sharia banking is needed.

The author is interested in researching the relationship-some ratio analysis in the financial statements using internal and external factor of sharia banking company. Internal factors used in this research are Non Performing Financing (NPF), Capital Adequacy Ratio (CAR), and Financing Deposit Ratio (FDR). While external factor used in this research is depositor funds (DPK). Based on the above description, the authors are interested to discuss the topic of "IMPACT OF NON PERFORMING FINANCE (NPF), CAPITAL ADEQUACY RATIO (CAR) AND FINANCING DEPOSIT RATIO (FDR) ON RETURN ON ASSET (ROA) WITH DEPOSITOR FUNDS AS A MODERATING VARIABLE IN ISLAMIC BANKS"

\section{LITERATURE REVIEW}

Based on Bank Indonesia Regulation Number 13/1 / PBI / 2011 concerning the Rating of Bank Commercial Banks, Banks are required to conduct a Bank Rating 
based on a risk-based approach called RGEC (Risk Profile, GCG, Earnings and Capital)

Bank performance is seen from four assessment factors in RGEC, namely:

1. Risk Profile uses calculation ratio of Non Performing Loan and Loan to Deposit Ratio.

2. Good Corporate Governance

3. Earnings, Using ROA (Return On Assets), ROE (Return On Equity), NIM (Net Interst Margin), BOPO (Operational Income Operating Cost).

4. Capital uses calculation of CAR ratio (Capital Adequacy Ratio).

\subsection{CAR (Capital Adequacy Ratio)}

Capital Adequacy Ratio (CAR) is a capital ratio that indicates the ability of banks to provide funds for business development and accommodate the possibility of risk of losses caused by bank operations. The greater the ratio the better the capital position (Achmad and Kusuno, 2003).

\subsection{FDR (Financing Deposit Ratio)}

FDR is the ratio between the amount of credit granted by the bank and the funds received by the bank. the minimum limit of bank loans is $80 \%$ and maximum $110 \%$.

\subsection{NPF (Non Performing Finance)}

NPF is the credit repayment rate given by depositors to the bank in other words NPF is the level of bad debts in the bank. NPF is known by calculating NonCurrent Financing Against Total Financing

\subsection{Depositor Funds (DPK)}

Depositor funds (DPK) are funds collected from the society by sharia banking. DPK in sharia banking consists of Al-Wadi'ah (wadi'ah) and Mudharabah

\section{RESEARCH METHOD}

\subsection{Conceptual Framework}

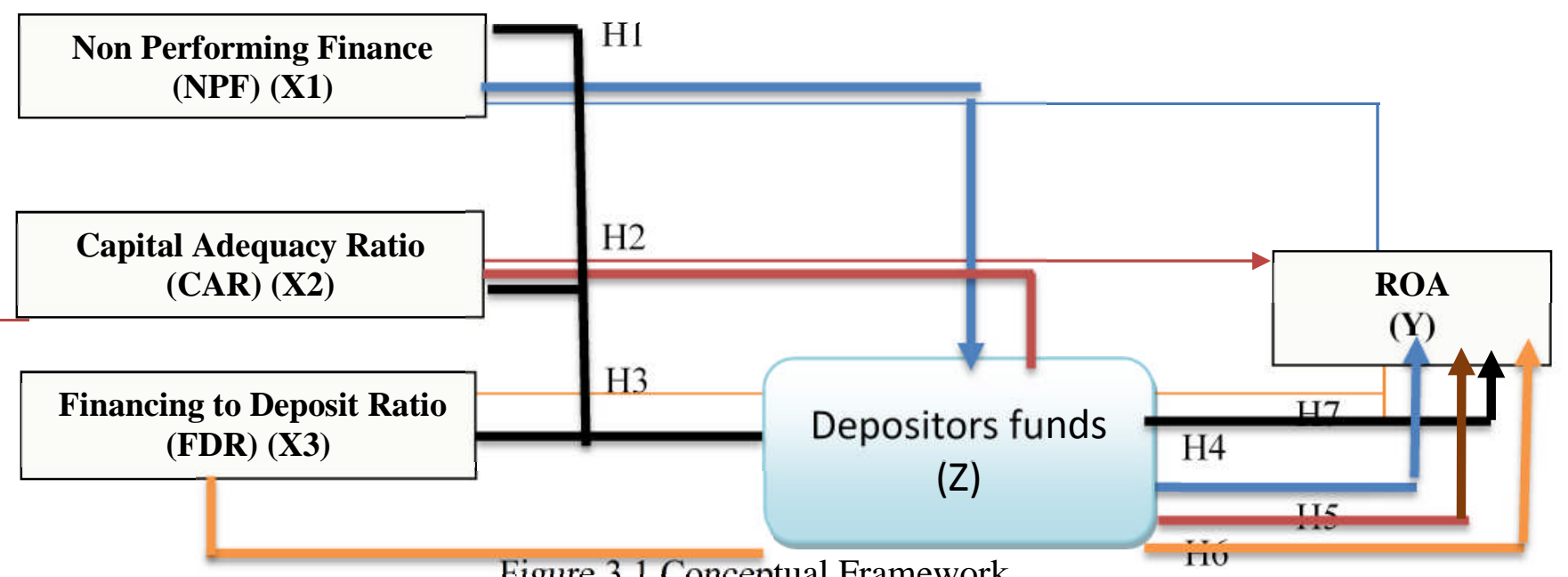

Figure 3.1 Conceptual Framework 


\subsection{Hypothesis development}

Based on the above conceptual framework, it can be formulated hypothesis as follows:

H1: Non Performing Financing (NPF) has a negative effect on ROA.

H2: Capital Adequacy Ratio (CAR) has a positive effect on ROA

H3: Finance to Deposit Ratio (FDR) has a positive effect on ROA

H4: Non Performing Financing (NPF) together with depositors funds (DPK) negatively affects the ROA of Sharia Banking ..

H5: Capital Adequacy Ratio (CAR) together with depositors funds (DPK) has an effect on positive ROA of Sharia Banking.

H6: Finance to Deposit Ratio (FDR) together with depositors funds (DPK) positively affects the ROA of Sharia Banking.

H7: Non Performing Finance (NPF), Capital Adequacy Ratio (CAR) and Financing to Deposit Ratio (FDR) and DPK together positively affect the ROA of Sharia Banking Industry

\subsection{Operational Definition and Variable Measurement Independent Variables}

Independent variable in this research is NPF (Non Performing Finance) (X1), CAR (Capital Adequacy Ratio) (X2) and FDR (Financing to Deposit Ratio) (X3)

\section{Moderating Variables}

In this reseach moderating variable used is depositors funds (DPK).

\section{Dependent Variable (Y)}

Dependent variable used in this research is Return On Asset (ROA). The scale used is the ratio

\subsection{Moderated Regression Analysis (MRA) testing}

The regression equation to test the hypothesis using the Moderated Regression Analysis (MRA) test approach or interaction test. According to Rosita (2015) MRA is a special application of multiple linear regression where in the regres: equation contains elements of interaction

\section{RESULT AND DISCUSSION}

\subsection{Descriptive Statistics}

Table 4.1 Descriptive Statistics

\begin{tabular}{|c|c|c|c|c|c|}
\hline & $\mathrm{N}$ & Minimum & Maximum & Mean & Std. Deviation \\
\hline ROA & 84 & ,001 & ,025 & ,01582 &, 006135 \\
\hline NPF & 84 & ,022 &, 058 & ,03916 &, 010204 \\
\hline CAR & 84 &, 11 & ,20 & , 1454 & ,02044 \\
\hline FDR & 84 & ,87 & 1,05 & ,9652 & ,04861 \\
\hline DPK & 84 &,- 047 & ,101 & ,02242 &, 025752 \\
\hline $\begin{array}{ll}\text { Valid } & \mathrm{N} \\
\text { (listwise) }\end{array}$ & 84 & & & & \\
\hline
\end{tabular}


Descriptive statistical analysis for profitability as measured by Return On Assets (ROA) has the lowest value of 0.01 percent while the highest value of 2.52 percent and the average value of $0.0158(1.58 \%)$ with a standard deviation of 0.00613. Non Performing Finance (NPF) has the lowest value of 0.02 while the highest value is 0.06 . The average value is $0.039(3.9 \%)$ and the standard deviation is 0.010 , the CAR has the lowest value of $0.11(11 \%)$ while the highest value is $0.20(20 \%)$ The average value is $14.54 \%$ and the standard deviation $2.044 \%$. The lowest FDR is $0.87(87 \%)$ and the highest is $1.05(105 \%)$ The average value is $96.52 \%$ and has a standard deviation of 0.04861

\subsection{Result of Moderated Regression Analysis (MRA) testing}

Table 4.2Result of Moderated Regression Analysis (MRA) testing

\begin{tabular}{|c|c|c|c|c|c|c|c|}
\hline \multirow{2}{*}{\multicolumn{2}{|c|}{ Model }} & \multirow[t]{2}{*}{$\mathrm{R}$} & \multirow[t]{2}{*}{$\begin{array}{l}\mathrm{R} \\
\text { Square }\end{array}$} & \multicolumn{2}{|c|}{$\begin{array}{l}\text { Unstandardized } \\
\text { Coefficients }\end{array}$} & \multirow[b]{2}{*}{$\mathrm{T}$} & \multirow[b]{2}{*}{ Sig. } \\
\hline & & & & $\mathrm{B}$ & Std. Error & & \\
\hline 1 & (Constant) & & & ,018 & ,015 & 1,193 & 237 \\
\hline & $\mathrm{NPF}$ & & &,- 349 &, 062 & $-5,670$ & 000 \\
\hline & CAR & & &,- 114 & 029 & $-3,905$ & 000 \\
\hline & FDR &, $698^{\mathrm{a}}$ & ,487 &, 028 & ,012 & 2,395 & 019 \\
\hline & DPK & & & ,783 &, 552 & 1,419 & 160 \\
\hline & NPF*DPK & & & 1,029 & 627 & $-6,244$ & 000 \\
\hline & CAR*DPK & & & ,391 & 167 & $-7,077$ & 000 \\
\hline & FDR *DPK & & & 190 & 039 & 4,858 & ,000 \\
\hline
\end{tabular}

a. Predictors: (Constant), DPK, NPF, FDR, CAR

b. Dependent Variable: ROA

Table 4.2 shows the $\mathrm{R}$ value of 0,698 or $69.8 \%$. This means that the relationship or correlation between NPF, CAR, FDR and Moderated to Return On Assets (ROA) is strong enough. R Square value of 0.487 or $48.7 \%$, it shows that ROA variable that can be explained by variable NPF, CAR, FDR and Moderated (DPK) is equal to $48,7 \%$.

From table 4.7 it can be seen that the variable of third party funds (DPK) has the significance of $0,000(\mathrm{NPF} * \mathrm{DPK} ; 0,000, \mathrm{CAR} * \mathrm{DPK} ; 0,000$ and FDR * DPK; $0,000)$ has fulfilled the sailing as moderating variable ie the sig value less than 0.05

\subsection{Hypothesis Testing}

T test results can be seen in the table coefficients in the sig column. (significant) is as follows

Table 4. 3 Result of $\mathrm{t}$ testing

\begin{tabular}{|c|c|c|c|c|c|c|}
\hline \multirow[b]{2}{*}{ Model } & \multirow[t]{2}{*}{$\mathrm{R}$} & \multirow[t]{2}{*}{ R Square } & \multicolumn{2}{|c|}{$\begin{array}{l}\text { Unstandardized } \\
\text { Coefficients }\end{array}$} & \multirow[b]{2}{*}{$\mathrm{T}$} & \multirow[b]{2}{*}{ Sig. } \\
\hline & & & $\mathrm{B}$ & Std. Error & & \\
\hline $1 \quad$ (Constant) &, $698^{\mathrm{a}}$ & , 487 &, 018 &, 015 & 1,193 & ,237 \\
\hline
\end{tabular}




\begin{tabular}{|l|l|l|l|l|l|}
\cline { 2 - 6 } NPF & &,- 349 &, 062 & $-5,670$ &, 000 \\
CAR & &,- 114 &, 029 & $-3,905$ &, 000 \\
FDR & &, 028 &, 012 & 2,395 &, 019 \\
DPK & &, 783 &, 552 & 1,419 &, 160 \\
\hline
\end{tabular}

a. Predictors: (Constant), DPK, NPF, FDR, CAR

b. Dependent Variable: ROA

\subsubsection{The first hypothesis (Ha 1$)$ test}

Based on Table 4.3 the value of regression coefficient of variable of NPF (X1) is equal to $-0,349$ or $34,9 \%$ which is negative value, hence increasing of NPF (X1) will decrease ROA (Y), first hypothesis states "Non Performing Financing (NPF) negative to acceptable ROA.

\subsubsection{The second hypothesis (Ha 2) test}

Table 4.3 shows the value of regression coefficient of variable CAR (X2) is 0.114 or $11.4 \%$ of negative value, then the second hypothesis that states "Capital Adequacy Ratio (CAR) positive effect on ROA rejected.

\subsubsection{The third hypothesis (Ha 3) test}

Based on the table is known that the value of regression coefficient variable FDR (X3) is equal to 0.028 or $2.8 \%$ which is positive, then the third hypothesis that states "Financing to Deposit Ratio (FDR) positive effect on acceptable ROA.

\subsubsection{Fourth Hypothesis (Ha 4) test}

Table 4.4 shows the value of the variable regression coefficient X4 (NPF * DPK) is 1.029 or $102.9 \%$ of positive value, the fourth hypothesis that states "Non Performing Finance (NPF) together with Third Party Fund (DPK) have a positive effect on ROA can be accepted.

Table 4.4 also shows that from the above coefficient data can be made moderated Regression Analysisn (MRA) equation as follows:

$\mathrm{ROA}=0,027-0,30 \mathrm{NPF}+1,029 \mathrm{NPF} * \mathrm{DPK}$

Table 4.4 Result of NPF MODERATED BY DPK test

Coefficients $^{\mathrm{a}}$

\begin{tabular}{|c|c|c|c|c|c|}
\hline \multirow[b]{2}{*}{ Model } & \multicolumn{2}{|c|}{$\begin{array}{l}\text { Unstandardized } \\
\text { Coefficients }\end{array}$} & \multirow{2}{*}{$\begin{array}{l}\text { Standardized } \\
\text { Coefficients } \\
\text { Beta }\end{array}$} & \multirow[b]{2}{*}{$\mathrm{T}$} & \multirow[b]{2}{*}{ Sig. } \\
\hline & $\mathrm{B}$ & Std. Error & & & \\
\hline $1 \quad$ (Constant) & ,027 & ,002 & & 11,288 & ,000 \\
\hline NPF & 300 & 057 &,- 499 & $-5,280$ & ,000 \\
\hline NPF*DPK & 1,029 & ,627 & ,155 & 1,642 & ,000 \\
\hline
\end{tabular}

a. Dependent Variable: ROA 


\subsubsection{The fifth hypothesis (Ha 5) test.}

Table 4.5 Result of CAR moderated by DPK

Coefficients $^{\mathrm{a}}$

\begin{tabular}{|c|c|c|c|c|c|c|}
\hline \multirow[b]{2}{*}{ Model } & & \multicolumn{2}{|c|}{$\begin{array}{l}\text { Unstandardized } \\
\text { Coefficients }\end{array}$} & \multirow{2}{*}{$\begin{array}{l}\text { Standardized } \\
\text { Coefficients } \\
\text { Beta } \\
\end{array}$} & \multirow[b]{2}{*}{$t$} & \multirow[b]{2}{*}{ Sig. } \\
\hline & & $\mathrm{B}$ & Std. Error & & & \\
\hline 1 & $\begin{array}{l}\text { (Constant) } \\
\text { CAR } \\
\text { CAR*DPK }\end{array}$ & $\begin{array}{l}, 023 \\
-, 061 \\
, 391\end{array}$ & $\begin{array}{l}, 005 \\
, 032 \\
167\end{array}$ & $\begin{array}{l}-, 203 \\
, 248\end{array}$ & $\begin{array}{l}5,020 \\
-1,909 \\
2,337\end{array}$ & $\begin{array}{l}, 000 \\
, 060 \\
, 022\end{array}$ \\
\hline
\end{tabular}

a. Dependent Variable: ROA

Table 4.5 shows the value of regression coefficient of variable X5 (CAR * DPK) is equal to 0.391 or $39.1 \%$ which is positive value, then the fifth hypothesis which states "capital adequacy ratio (CAR) together with Third Party Fund (DPK) have positive effect on ROA be accepted. And can be made equation of moderated Regression Analysisn (MRA) as follows:

$\mathrm{ROA}=0,023-0,61 \mathrm{CAR}+0,391 \mathrm{CAR} * \mathrm{DPK}$

\subsubsection{Hypothesis sixth (Ha 6) test}

Table 4.6 shows that the value of X6 regression coefficient variable (FDR * DPK) is equal to 0.073 or $7.3 \%$ which is positive value, the fifth hypothesis which states FDR along with Third Party Fund (DPK) have positive effect on acceptable ROA. And can be made equation of moderated Regression Analysisn (MRA) as follows: $\mathrm{ROA}=-0,045+0,61 \mathrm{FDR}+0,073 \mathrm{FDR} * \mathrm{DPK}$

\subsubsection{The seventh Hypothesis (Ha 7) test}

In table 4.7 shows that Non Performing Finance (NPF), Capital Adequacy Ratio (CAR) and Financing to deposit ratio (FDR) and DPK jointly have a positive effect on ROA of Sharia Banking industry can be accepted

Table 4.6 Result of FDR moderated by DPK

Coefficients $^{\mathrm{a}}$

\begin{tabular}{|c|c|c|c|c|c|c|}
\hline \multirow[b]{2}{*}{ Model } & & \multicolumn{2}{|c|}{$\begin{array}{l}\text { Unstandardized } \\
\text { Coefficients }\end{array}$} & \multirow{2}{*}{$\begin{array}{l}\text { Standardized } \\
\text { Coefficients } \\
\text { Beta }\end{array}$} & \multirow[b]{2}{*}{$\mathrm{t}$} & \multirow[b]{2}{*}{ Sig. } \\
\hline & & B & Std. Error & & & \\
\hline \multirow[t]{3}{*}{1} & (Constant) &,- 045 & ,011 & & $-3,982$ &, 000 \\
\hline & FDR & ,061 & ,012 & , 486 & 5,264 &, 000 \\
\hline & FDR*DPK &, 073 & ,024 & ,287 & 3,107 & ,003 \\
\hline
\end{tabular}

a. Dependent Variable: ROA

Table 4.7 Result of $T$ Testing

Coefficients

\begin{tabular}{|c|c|c|c|c|c|c|}
\hline \multirow[b]{2}{*}{ Model } & & \multicolumn{2}{|c|}{ Unstandardized Coefficients } & \multirow{2}{*}{$\begin{array}{l}\text { Standardized } \\
\text { Coefficients } \\
\text { Beta } \\
\end{array}$} & \multirow[b]{2}{*}{$\mathrm{T}$} & \multirow[b]{2}{*}{ Sig. } \\
\hline & & $\mathrm{B}$ & Std. Error & & & \\
\hline 1 & (Constant &, 018 &, 015 & & 1,193 & ,237 \\
\hline & NPF &,- 349 &, 062 &,- 581 & $-5,670$ &, 000 \\
\hline & CAR &,- 114 & 029 &,- 380 & $-3,905$ &, 000 \\
\hline
\end{tabular}




\begin{tabular}{|l|l|l|l|l|l|}
\hline FDR &, 028 &, 012 &, 224 & 2,395 &, 019 \\
DPK &, 783 &, 552 &, 118 & 1,419 &, 160 \\
\hline
\end{tabular}

a. Dependent Variable: ROA

\subsection{Discussion}

4.2.1 The effect of Non Performing Finance (NPF) on Return On Asset (ROA)

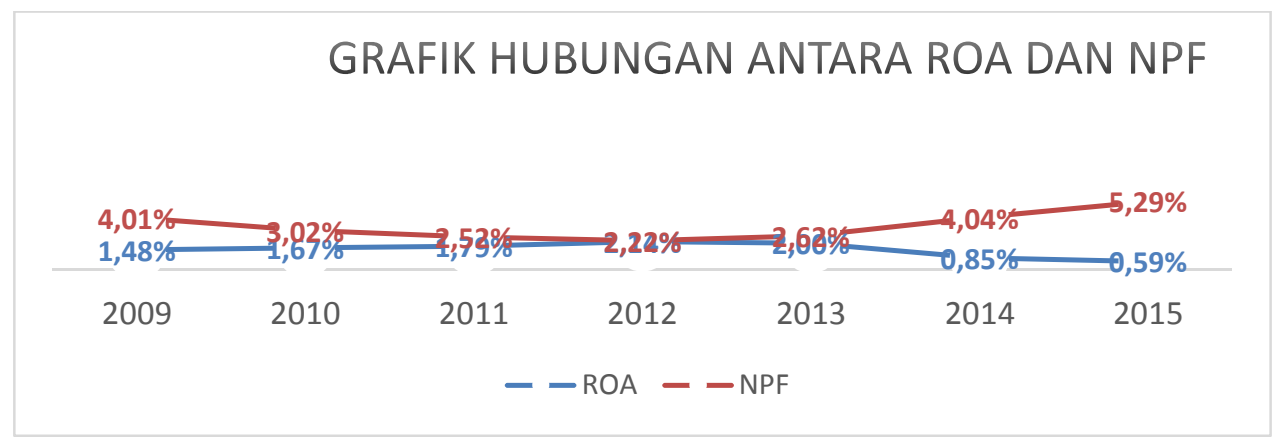

Figure 4.2

Figure 4.2 shows non-performing loans indicated by Non Performing Financing (NPF) has a negative effect on profitability. This is evident from the NPF ratio of 2010 to 2015, when the NPF decreased from 2.52 to 2.22, (20112012), ROA increased from 1.79 to 2.14 (2011 - 2012), as well as in year 2013 and 2014 NPF increased by $1.42 \%$, ROA decreased by $1.15 \%$

\subsubsection{The Effect of Capital Adequacy Ratio (CAR) on Retun On Asset (ROA)}

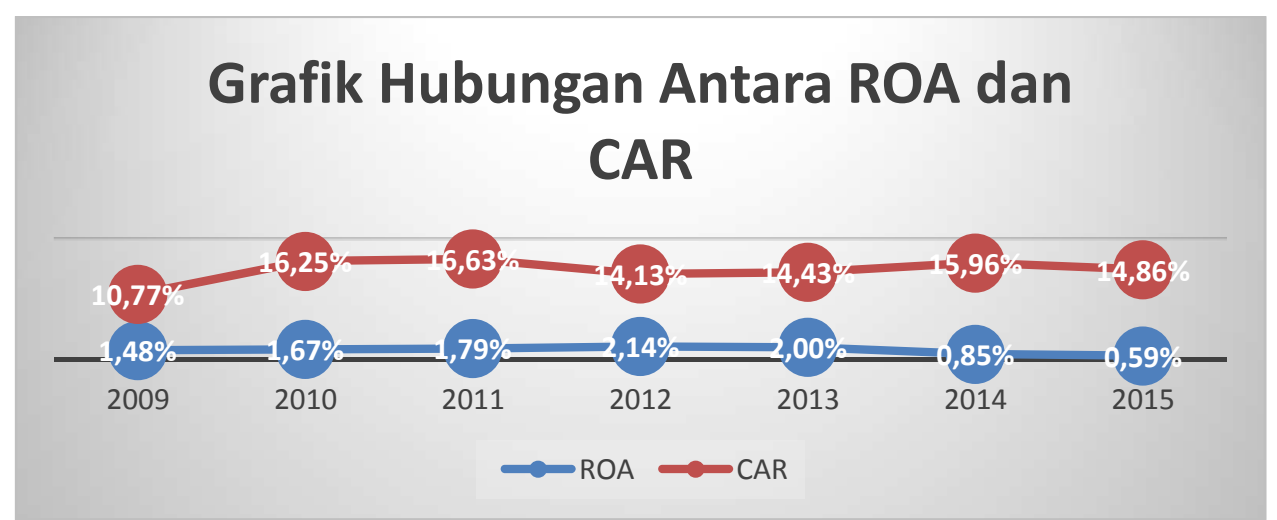

Figure 4.3

Capital adequacy ratio indicated by Capital Adequacy ratio (CAR) has negative effect on profitability. This is evident from when CAR also decreased 16.63 to 14.13 (2011 - 2012), ROA increased from 1.79 to 2.14 (2011 - 2012), and vice versa in 2013 and 2014 CAR has increased by $1.53 \%$, ROA decreased by 1.15 


\subsubsection{The Effect of Financing to Deposit Ratio (FDR) on Retun On Assets (ROA)}

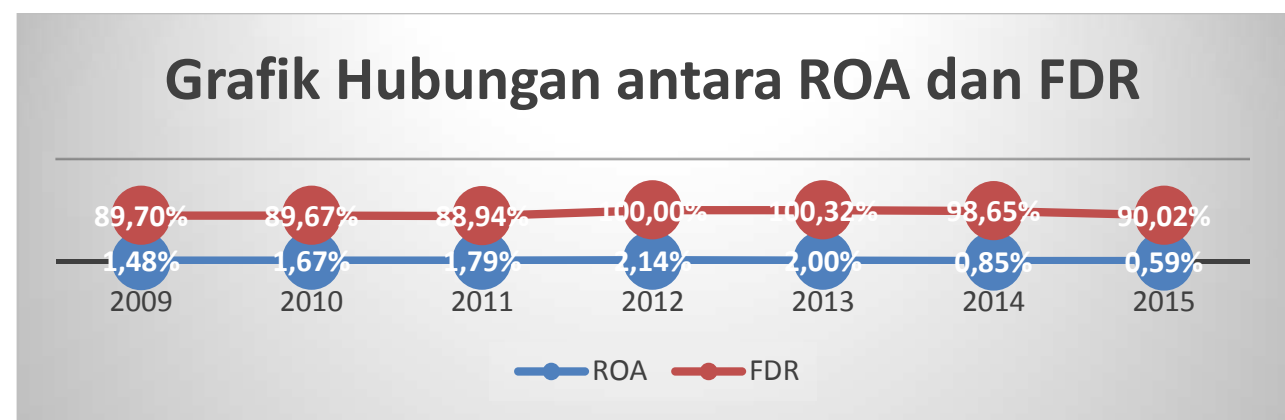

Figure 4.4

This study concludes that when FDR increases this will increase the profitability of sharia banking, it is seen in 2011 to 2012 and 2012 to 2013, where FDR has increased respectively by $0.35 \%$ and $0.32 \%$, profitability / Margin for the results of Islamic banking (ROA) also increased each of $0.35 \%$ and $0.14 \%$

\subsubsection{The Influence of Non Performing Finance (NPF) with Depositors Funds (DPK) to Return On Assets (ROA)}

\begin{tabular}{|c|c|c|c|c|c|c|c|c|c|}
\hline \multicolumn{5}{|c|}{ The Influence of NPF To ROA } & \multicolumn{5}{|c|}{ The Influence of NPF with DPK to ROA } \\
\hline Model & $\mathbf{R}$ & $\begin{array}{c}R \\
\text { Square }\end{array}$ & $\begin{array}{c}\text { Adjusted } \\
\text { R } \\
\text { Square }\end{array}$ & $\begin{array}{l}\text { Std. Error } \\
\text { of the } \\
\text { Estimate }\end{array}$ & Model & $\mathbf{R}$ & $\begin{array}{c}R \\
\text { Squar } \\
e\end{array}$ & $\begin{array}{l}\text { Adjuste } \\
\text { d R } \\
\text { Square }\end{array}$ & $\begin{array}{c}\text { Std. } \\
\text { Error of } \\
\text { the } \\
\text { Estimate }\end{array}$ \\
\hline &, 503 & ,253 &, 244 &, 005335 & 1 &, 526 &, 277 &, 259 &, 00528 \\
\hline
\end{tabular}

The above data (Table 4.8) illustrates that the fourth hypothesis that there is a positive influence between NPF and DPK on ROA is acceptable and DPK strengthens the influence of NPF to Roa, as evidenced by the increasing R Square (0.253 to 0.277$)$.

\subsubsection{Influence of Capital Adequacy Ratio (CAR) with Depositors Funds (DPK) to Return On Asset (ROA).}

The data in the table (Table 4.9) illustrates the effect of CAR on ROA is $15.2 \%$, but when CAR and DPK in affecting profitability (ROA) decreased to $9.4 \%$, it shows that DPK weakens the relationship between CAR and ROA, the capital ratio followed by the increase in Depositors funds (DPK) will decrease ROA.

Table 4.9

Table Comparison of CAR and CAR effects along with DPK on ROA

\begin{tabular}{|c|c|c|c|c|c|c|c|c|c|}
\hline \multicolumn{5}{|c|}{ The Influence of CAR To ROA } & \multicolumn{5}{|c|}{ The Influence of CAR with DPK to ROA } \\
\hline Model & $\mathrm{R}$ & $\begin{array}{c}\mathrm{R} \\
\text { Square }\end{array}$ & $\begin{array}{c}\text { Adjusted } \\
\text { R } \\
\text { Square }\end{array}$ & $\begin{array}{l}\text { Std. Error } \\
\text { of the } \\
\text { Estimate }\end{array}$ & Model & $\mathrm{R}$ & $\begin{array}{c}\text { R } \\
\text { Squar } \\
\text { e }\end{array}$ & $\begin{array}{c}\text { Adjuste } \\
\text { d R } \\
\text { Square }\end{array}$ & $\begin{array}{c}\text { Std. } \\
\text { Error of } \\
\text { the } \\
\text { Estimate }\end{array}$ \\
\hline 1 &, 390 & ,152 & ,121 &, 005753 & 1 & 306 & 094 & , 071 &, 00591 \\
\hline
\end{tabular}




\subsubsection{The Influence of Financing to Deposit Ratio (FDR) with Depositors Funds (DPK) on Return On Assets (ROA)}

Table 4.10 Comparison of the effects of FDR and FDR along with DPK on ROA

\begin{tabular}{|c|c|c|c|c|c|c|c|c|c|}
\hline \multicolumn{5}{|c|}{ Influence FDR To ROA } & \multicolumn{5}{|c|}{ Influence FDR with DPK to ROA } \\
\hline Model & $\mathrm{R}$ & $\begin{array}{l}\mathrm{R} \\
\text { Square }\end{array}$ & $\begin{array}{l}\text { Adjusted } \\
\text { R Square }\end{array}$ & $\begin{array}{l}\text { Std. Error } \\
\text { of the } \\
\text { Estimate }\end{array}$ & Model & $\mathrm{R}$ & $\begin{array}{l}\mathrm{R} \\
\text { Square }\end{array}$ & $\begin{array}{l}\text { Adjusted } \\
\mathrm{R} \\
\text { Square }\end{array}$ & $\begin{array}{l}\text { Std. Error } \\
\text { of the } \\
\text { Estimate }\end{array}$ \\
\hline 1 & ,476 & ,227 & ,217 &, 005427 & 1 & ,587 & ,344 & ,320 &, 005060 \\
\hline
\end{tabular}

The data in table 4:10 shows the effect of FDR on ROA is $22.7 \%$, but when FDR with DPK in affect profitability (ROA) increased to $34.4 \%$, it shows that DPK strengthens the relationship between FDR and ROA, the financing ratio followed by the increase in Third Party Funds (DPK) will increase in ROA.

\subsubsection{The Influence of Non Performing Finance (NPF), Capital Adequacy Ratio (CAR), Financing to Deposit Ratio (FDR) with Depositors Funs (DPK) to Return On Assets (ROA)}

This research concludes that Non Performing Finance (NPF), Capital Adequacy Ratio (CAR) and Financing to deposit Ratio (FDR) and DPK together have a significant effect on Sharia Banking ROA. This can be seen from the probability (sig-t) value for independent variables, namely Non Performing Finance (NPF), Capital Adequacy Ratio (CAR), Financing to Deposit Ratio (FDR) with Third Party Funds $(0.000,0.000,0,019$ and 0,160), this value is smaller compared to 0.05 , except DPK of 0.160 above 0.05 . so it can be concluded that simultaneously exogenous variables have a significant effect on endogenous variables. Result of statistical test by using spss 23 program, got that $F$ count equal to 24,053 , while value of $F$ table equal to 2,49 . (df $1=5-1 ; 4$ and df $2=84-5 ; 79)$. The value of $F$ arithmetic $>F$ table, and in the calculation through the program SPSS 23 in get sig value $=, 000$, it means sig $<0,05$ so it can be concluded that simultaneously exogenous variable is non performing finance (npf), capital adequacy ratio (car) and financing to deposit ratio (frd) have a significant effect on endogenous variable that is return on asset (roa). The results of this study if inserted into the input model, process and outcome (the input process - output Model) proposed by Barry Collins and Harold Guetzkow, can be described as follows :

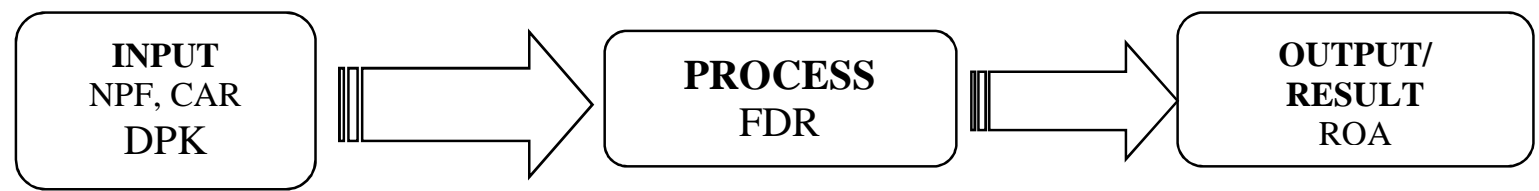

Figure : 4.5

Input, Process and Output Model 
Information :

- NPF and CAR have negative effect on ROA, with coefficient of $34.9 \%$ and $11.4 \%$, it shows that NPF has a bigger effect on decreasing ROA than CAR. While FDR have positive effect to ROA, with coefficient value equal to 2,8\%

- The model and the results of this study indicate that management should focus lower NPF so that profitability level can increase significantly, because NPF has a very big influence on the decrease of ROA

\section{CONCLUSIONS}

Based on the results of research conducted through statistical testing using regression analysis and moderating regression analysis (MRA) and the discussion has been presented in the previous chapters it can be concluded some of the following:

1) Non Performing Financing (NPF) has a negative effect on ROA on Sharia Banking in 2009 - 2015, with a probability value (sig-t) of 0.000 and the value of regression coefficient variable NPF (X1) is -0.349 or $34.9 \%$ is negative.

2) Capital Adequacy Ratio (CAR) has a negative effect on ROA on Sharia Banking in 2009 - 2015, with a probability value (sig-t) of 0,000 and its variable regression coefficient of -0.114 or $11.4 \%$ is negative.

3) Finance to Deposit Ratio (FDR) has a positive effect on ROA on Sharia Banking in 2009 - 2015, with probability value (sig-t) of 0.019 and variable regression coefficient of 0.028 or $2.8 \%$ which is positive.

4) Non Performing Finance (NPF) together with Third Party Funds has no significant effect on ROA in Sharia Banking in 2009 - 2015, with a value of probability significance of 0,000 and the value of the regression coefficient variable is 1.029 or $102.9 \%$ which is positive.

5) Capital adequacy ratio (CAR) together with Third Party Fund (DPK) has a positive effect on ROA on Sharia Banking in 2009 - 2015, with a probability value of significance of 0.022 and the value of variable regression coefficient of 0.391 or $39.1 \%$ which is positive .

6) Financing to deposit ratio (FDR) together with Third Party Fund (DPK) has a positive effect on ROA. With probability value of significance equal to 0,003 and value of variable regression coefficient equal to 0,073 or $7,3 \%$ which have positive value.

7) Non Performing Financing (NPF), Capital Adequacy Ratio (CAR) and Financing to Deposit Ratio (FDR) and DPK together have a positive effect on ROA of Sharia Banking industry, with F test value of 24.053, and F table of 0.846 and $\mathrm{F}$ cal> $\mathrm{F}$ table.

\section{REFERENCES}

Ade Sasongko, R., Pramudhito. (2014). Anayisis of the impact of Car, Npf, Bopo, Fdr, and Ncom to Profitability Sharia bank in Indonesia. Diponogoro University. 
Ghozali, Imam. (2012). The Aplication of Multivariate Analysis with SPSS Programme. Diponegoro University; Semarang.

Ismawati, Dwi. (2009). The influence of FDR, Cash Ratio, CAR and DPK to profitability. Skripsi ; Universitas

Negeri Sunan Kalijaga ; Yogyakarta.

Machmud, Amir dan Rukmana, Bank Syariah Theory, Policy dan Emphiris Study In Indonesia. (2010). Erlangga, Jakarta

Muhammad, (2000). System dan Operational Procedure Islamic Bank. UII Press, Yogyakarta,

M. Algaoud, Latifa, Mervyn K. Lewis. (2003). Sharia banking. Serambi Ilmu Semesta, Jakarta.

Pujiati,Desi, Maria Ancela, Beny Susanti, dan Mujiyani. (2013). The Influence of Non Performing Loan Capital Adequacy Ratio and Depositors Funds to credit in Pt. BCA, Tbk; Jurnal Proceeding Pesat Universitas Gunadarma.

Rivai, Veithzal. (2007). Bank dan Financial Institution Management ; Convencional \& Sharia System. Jakarta : PT. Raja Grafindo Persada

Setiawati Ratu Edo, Delsy dan Ni luh Putu Wiagustini (2014). The influence of Depositors Funds Non Performing Loan, and Capital Adequacy Ratio to Loan To Deposit Ratio and Return On Assets in bank sectori in sector Bursa Efek Indonesia. E Journal Ekonomi dan Bisnis Universitas Udayana. 3.11

Shalhuddin Fahmi_M. (2013). The influence of CAR, NPF, BOPO and FDR to Profitabilitas Bank Umum Syariah. Universitas Islam Negeri Syarifhidayatiullah.

Sudarsono, Heru. (2008). Bank and other Sharia bank Descripsion dan lilustratoni 3rd illustration 3, Yogyakarta : Ekonisia

Suryani; (2011). Analize of the influence Financing To Deposit Ratio (Fdr)Terhadap Profitabilitas Perbankan Syariah Di Indonesia. Jurnal Vol 19 Universitas Islam Negeri Walisongo. 